\title{
Paksi Naga Liman Carriage A Multicultural Symbol of Caruban Nagari: Enculturation of Nusantara Arts in Cultural Arts Education
}

\author{
Indah Fikriyyati ${ }^{1, *}$, I Wayan Suardana ${ }^{2, * *}$ \\ ${ }^{1}$ Arts Education Graduate Program, Yogyakarta State University, Depok 55281, Yogyakarta, Indonesia \\ ${ }^{2}$ Department of Fine Arts Education, Yogyakarta State University, Depok 55281, Yogyakarta, Indonesia \\ *Corresponding author. Email: indahfikriyyati@yahoo.com \\ *Corresponding author.Email: wayan_suardana@uny.ac.id
}

\begin{abstract}
Cirebon is a multicultural area. The word 'Cirebon' comes from the word 'caruban' which means a mixture. Since the mid-15th century, there have been several census statistical data on various tribes in Cirebon, such as Javanese, Sundanese, Chinese, Persian, Majapahit, and others. Therefore, Paksi Naga Liman is a form or symbol of the multiculturalism of national and state life itself. Paksi Naga Liman carriage is Sultan Kanoman's magnificent wagon. This carriage contains the teachings of 'Hablu Minal Alam,' which is the union of three animal elements that live in three different realms, namely air, sea, and land. However, so far, Cirebon has not fully applied or incorporated the existing art forms in the Paksi Naga Liman carriage in the world of education, especially in schools, so that there are few students of elementary, junior high, or even high school who understand that Paksi Naga Liman carriage embodies multicultural values that represent the diversity of cultures, races, religions, and ethnicities in Cirebon. This study was carried out using a qualitative descriptive approach in which the data collection was carried out through field studies in the form of interviews, observations in Kanoman Palace museum, document analysis on the meanings of each symbol engraved in the carriage, and literature study.
\end{abstract}

Keywords: multicultural, paksi naga liman, Cirebon

\section{INTRODUCTION}

Growing old in life is a sure thing but growing old without knowing our own culture and arts is futility. A Wiseman said: "Live with the Work, so when you die people will always remember you through your work". The researchers of this study fully believe in that saying because the world is not immortal.

The aforementioned saying has been trusted long before the new order era by the elders and ancestors. They designed and made an artwork using simple tools and materials; thus, their artwork and philosophy still exist and are relevant in this day and age.

However, there is a problem in defining education especially Cultural Arts Education in schools today. Indonesian culture, as we know it, is a condition constructed by various areas and tribes developing in accordance with their historical demands. Experiences and the ability of regions to meet the target shape the culture itself. [1]

In this paper, the researchers select one out of four kingdoms in Cirebon, namely Kanoman kingdom. The other three kingdoms are Kasepuhan, Kaprabonan, and Kacirebonan kingdoms. Kanoman is chosen since the researcher is interested in writing about Paksi Naga Liman carriage which shows the existence of the kingdom. Out of curiosity about life in the palace, the idea to research the arts of the kingdom comes up.

In addition to the various reasons explained above, the researchers found that Paksi Naga Liman carriage is constructed from various cultures or multiculturalism in the world. With modern technology embodied on the carriage, the master craftsman was able to create such a wonderful technology that can compete with the European works and attract many people's attention.

\section{RESEARCH METHOD}

To study Paksi Naga Liman Carriage, researchers referred to Bronislaw Malinowski's functionalism theory. The theory of functionalism is one of the theories used in social science emphasizing the interdependence between institutions and habits in certain societies. Function 
analysis explains how social structure is supported by institutional functions such as state, religion, family, and ethnicity. Bronislaw Malinowski then develops a new theoretical framework for analysing the function of human culture that called cultural functionalism theory or functional theory of culture [2] [3].

Based on the previously outlined and explained problems, the researchers were interested in conducting research on Paksi Naga Liman carriage, the Multicultural Symbol of the Caruban Nagari Society: Enculturation of the Archipelago Art in Cultural Arts Education using the art and culture approach. This research employed the descriptive qualitative method to precisely explain individual characteristics and symptoms presented by certain groups to define the frequency of a certain relationship among symptoms in a society. There had been hypotheses depending on the knowledge about the problems in this study. [4]

Moreover, the researchers examined the results of observations and conducted interviews with interviewees who really understood the history Paksi Naga Liman carriage in Kanoman palace. Interviews with certain figures focused on specific information. The interviews involved influential and prominent figures who knew a lot about an organization or community in relation to Kanoman Palace. Curators, performance managers, experts, critics, and artists were included in accordance with their expertise. [5]

The researchers are open for correction and hope that the result of this study will be beneficial for readers.

\section{DISCUSSION}

\subsection{History of Paksi Naga Liman Carriage}

During the research process, the researchers needed to look for primary and secondary data from the society as well as archaeologists and philologists. The time when Paksi Naga Liman carriage was made is the age when metal and wood were mostly used, but it seems that the carriage craftsman was already familiar with advanced technology.

Ifful Azka, a Cirebon cultural observer working as a royal servant in Kanoman Palace, when interviewed stated that:

"Speaking of Paksi Naga Liman is speaking of history, speaking of Paksi Naga Liman means speaking of Archaeology, speaking of Paksi Naga Liman also means speaking of Art, especially fine arts, speaking Paksi Naga Liman means Technology of the past, speaking Paksi Naga Liman can also mean speaking of passwords, symbols, icons."

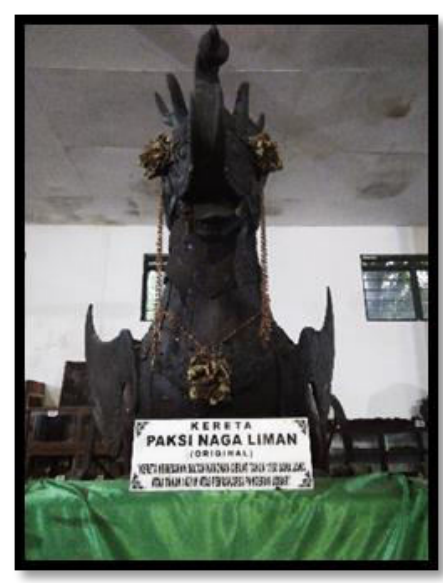

Figure 1 The Original Paksi Naga Liman Carriage in Benda Pusaka Museum of Kanoman Palace (personal documentation)

Paksi Naga Liman was Kanoman King's great carriage. It is the vehicle of Bhatara Indra (the god of war). It is said that in 1400 Prince Cakra Buana attacked Palimanan using this carriage. Some even said that the carriage might have been made previously. Bhatara Sri Pertiwi or well known as Sri Jaya Bupati used Paksi Naga Liman carriage in the year of 1030-1040 M. Then in 1040-1042, there was an idea to separate Galuh and Singapura Kingdom. The two kingdoms were previously one but then Sri Jaya Bupati took over the throne before the separation. [6]

In terms of history, the carriage was made in 1428 by an unknown figure since no data are found relating to the designer. The carriage is in a good condition now. This means that it is well maintained. According to the data obtained by Kanoman Palace, a modification was once carried out by Prince Losari from the end of the fifteenth century to the mid of the sixteenth century. The next modification was carried out by Sunan Gunung Jati from the end of 1400 to the mid of 1500 . So far there are no specific data on parts of the carriage being modified by prince Losari. However, there is a public assumption that prince Losari (the great-grandson of Sunan Gunung Jati) himself made the carriage. However, this information needs to be verified since it is illogical that a greatgrandson made a war wagon for his great grandfather Then, there is an assumption that the prince only modified the carriage because the identity of the craftsman is still unknown. Based on the interview conducted by the researchers, that prince Losari is the carriage craftsman can neither be right nor wrong. It is supported by the declaration of Kanoman palace that the craftsman identity is unknown. 


\subsection{Paksi Naga Liman Design Character and Symbol}

Paksi Naga Liman engraving contains elements of arts and monotheism although it was made in the era of Prince Cakra Buana in between the pre-Islamic era and the Islamic era in which Hinduism altered into Islam. The Hinduism values are represented in paksi (birds) as the symbol of god Vishnu and Vishnu sects which altered with the Shiva sects symbolized by liman (elephant) or Ganesha, the son of Shiva and Parvati. This shows the merge or acculturation of sects.

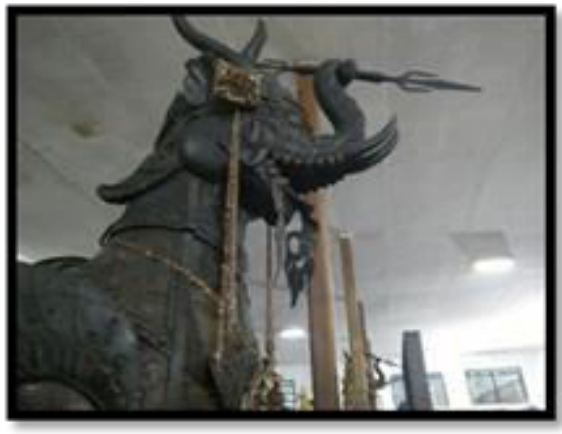

Figure 2 The Ornament in Paksi Naga Liman Carriage (personal documentation)

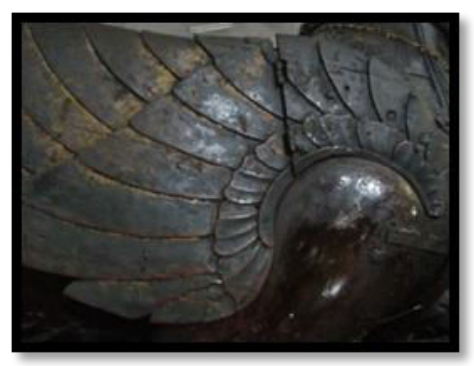

Figure 3 The Ornament in Paksi Naga Liman Carriage (personal documentation)

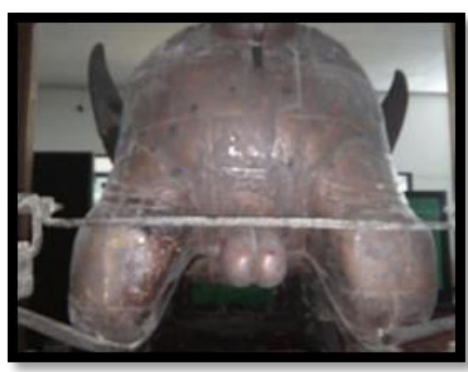

Figure 4 The Back Part of Paksi Naga Liman Carriage

There are various kinds of ornaments decorating Paksi Naga Liman carriage, and most of decoration are plant ornaments. In the front part of the carriage, Candrasengkala (a chronogram) represents the age based on the month it was made. There is actually a principle of Hablu Minal Alam in the carriage. It is an incorporation of three animal elements living in three different realms, namely air, sea, and land. In the Majapahit Kingdom, there is a concept of Benawa Sekar; Benawa is name of a sea ship and Sekar is a flower. Benawa Sekar developed civilization living under the sea. However, different from that of Majapahit, the concept of Paksi Naga Liman carriage is more about a war wagon with a trident symbolizing the high degree [7]. Based on the information obtained in the interview with Elang Ayi (a family member of the palace), the tongue and wing of Naga Liman once could swift. The carriage was at last used by Sultan Dzulkarnain, the eighth king of Kanoman Palace, before stored in the museum.

\section{A MODERN INTERPRETATION OF PAKSI NAGA LIMAN}

Modern interpretations were born in the modern age. In the old days, military technology has existed. The elephant is the symbol of an army, the dragon symbolizes the navy, and the bird represents the air force. The bird is also the symbol of knowledge that can reach the space. Dragon means the economy route, while the elephant represents power.

\subsection{Multicultural Values in Paksi Naga Liman}

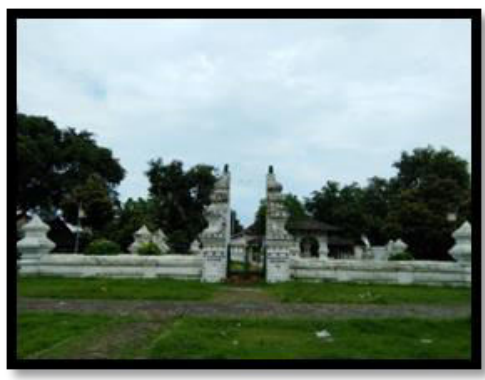

Figure 5 The Front Look of Kanoman Palace (personal documentation)

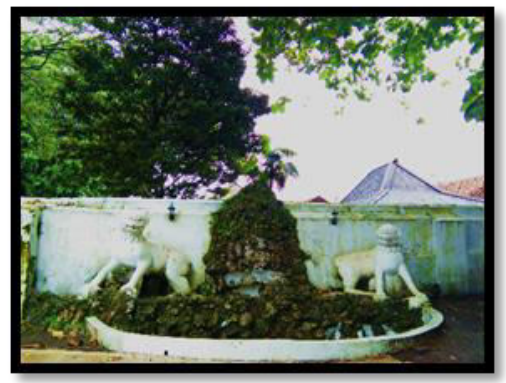

Figure 6 The Area of Kanoman Palace (personal documentation) 
Discussing Cirebon as a multicultural area, the term Cirebon comes from the word Caruban which means mixture. Since the mid of 15 th century there have been several data obtained from some tribes, such as Javanese, Sundanese, Chinese, Persians, Majapahit, etc. Because there have been multicultural ethnicities in Cirebon, the carriage itself is the symbol of multiculturalism. Since the Singaporean era, people have come by to visit Mura Djati harbour. The head, Ki Gedhe Muara Djati or known as Ki Gedeng Jumanjang Djati accepted various religions and implemented multicultural values from various ethnicities, cultures, and religions. Thus, Prince Cakra Buana and Sunan Gunung Jati assumed that Paksi Naga Liman is a result of art, religion of the mentioned tribes, as well as Chinese, Gujarat, and India assimilation.

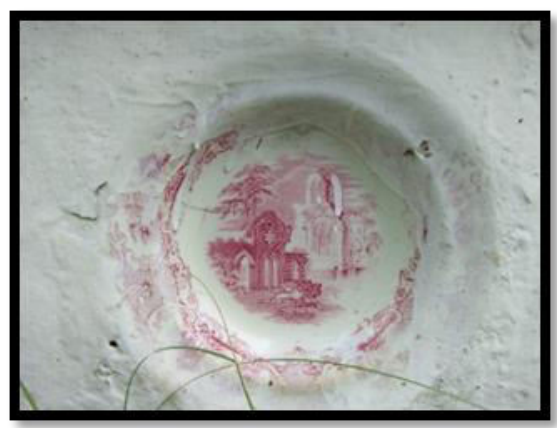

Figure 7 The Plate Attached in the Palace Wall (personal documentation)

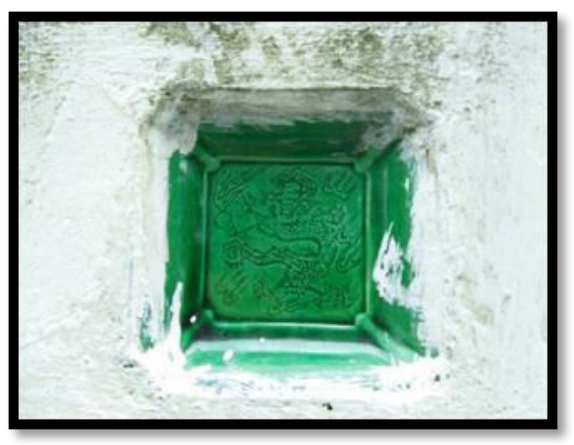

Figure 8 The Plate Attached in the Palace Wall (personal documentation)

The assumption that Chinese, Middle Eastern, and Indian cultures were assimilated in Paksi Naga Liman proves by the architectures in the palaces in Java. Most of the palaces have Chinese, Indian, and Middle Eastern elements. Those three elements are three principles of Indonesian palace architecture and the representation of Paksi Naga Liman.

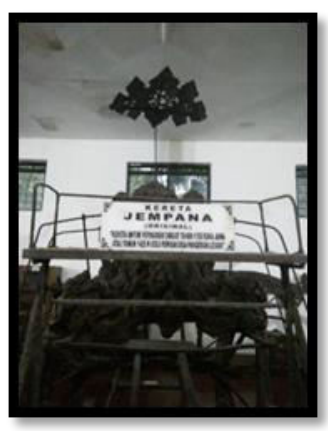

Figure 9 Jempana Carriage (personal documentation)

In addition to the Naga Liman carriage, Kanoman Palace has another carriage called the Jempana. Most people said it was to carry the empress, [8] but others say that Jempana carriage was once a hearse. Jempana has many ornaments carved in almost its entire body. There is also a mega mendung (A batik motif made by Cirebon people) engraved in its body.

The philosophy of mega mendung engraving means the balance of nature. Moreover, Jempana has plant, animal, and hexagon engraving that represent the six ahlul bait (Prophet Muhammad, Siti Fatimah, Sayyidina Ali, Sayyidina Hasan, Sayyidina Husen, and Saint Gabriel). It was not only interpreted as ahlul bait since other people argue that it represents "Jinem Pangrawit" (Jinem: one, Pangra: descendants of Wit: early). It means the early life or Nuur Muhammad as written in Hadith. The hexagon is present in a Javanese song entitled "lir ilir" in which one of the lyrics contains blimbing kui (starfruit-a fruit commonly has five sides, but there must one with six sides).

"cah angon cah angon, penekno blimbing kuwi, lunyulunyu penekno kanggo basuh dodot iro"

In the past, starfruit (blimbing) was used to wash clothes because it contains sodium carbonate.

\subsection{Implementation in Education}

Provided by information from interviewees, the researchers conclude that the schools in Cirebon have not applied or included any fine art element in lessons. Thus, many elementary, junior high, and senior high school students do not know the fact that Paksi Naga Liman carriage was constructed of multicultural values representing that Cirebon has various cultures, races, religions, ethnics, which makes it a Caruban Nagari or Mixed Country. 
Local wisdoms, particularly Paksi Naga Liman needs to be instilled in learning. Although the newest curriculum has put local wisdoms in each culture and art lesson, the knowledge and philosophy of Paksi Naga Liman carriage have never been introduced to students. Aesthetic education in art education has an important role in improving students' aesthetic sensitivity (Pamadhi). The sensitivity builds their souls and improves their brain functions. It is true that the curriculum implemented in schools will never be achieved completely. However, some experts suggest that there is a need to develop a hidden curriculum to improve and revise the developed curriculum

Some education experts in various countries propose the development of educational curriculum units based on basic needs. These basic needs are related to history, culture, and the environment controlling lives. A curriculum should not be based on temporary needs because it should be based on longitudinal term needs involving the nation.

Art education in Indonesia basically has a vision because other nations have seen the potential and advantages that it has. For example, Indonesian art as a legacy from the ancestors of the nation has specific character and style, but after influenced by other nations, Indonesian art experiences degradation in terms of quality.

\section{CONCLUSION}

The name Cirebon is derived from the commonly known words Cai (water) and Rebon (shrimp). However, according to other references, Cirebon is derived from Cere-ibuan which means motherland. Then, many people question the statement arguing that if Bhatara Sri Pertiwi harmonized in Sitinggil (a building with high-quality architecture located in Kanoman Palace) is the mother, who the father is. There should be a father who separated Galuh and Singapore into two in 1042. Galuh got Cererama'i which now becomes Ciremai.

Cirebon is constructed of various ethnic and cultural groups. Influenced by other countries, Cirebon is now inhabited by different ethnics with different languages. The acculturation taking place in the Islamic era was done by Sunan Gunung Jati. The influences of India, Arabic countries and China can be seen clearly in Paksi Naga Liman carriage located in Kanoman palace. The carriage is estimated to be made in 1428 by a craftsman whose identity is still unknown.

Many references mention that Prince Losari is the one behind the carriage design, but after conducting this research, the researchers are sure that prince Losari only modified the carriage. The multicultural values in Paksi Naga Liman carriage has a very deep philosophy. The elephant, dragon, and bird represent the Cirebon situation and culture at that moment and are still relevant to the situation at this age. In fact, the values can be instilled in education so that students know its history as well as the local wisdom and artwork from their city. It is hoped that the government pays more attention to Paksi Naga Liman carriage and puts it in the curriculum.

\section{REFERENCES}

[1] Kayam, Umar. Seni, Tradisi, Masyarakat [Art, Tradition, Society]. No. 3. Penerbit Sinar Harapan, 1981. p. 16.

[2] Malinowski, Bronislaw. "The functional theory." A Scientific Theory of Culture (1944): 145-76. p. 172.

[3] Koentjaraningrat. Sejarah teori antropologi. Penerbit Universitas Indonesia (UI Press), 1990.

[4] Koentjaraningrat, R. M. Kebudayaan, Mentalitas dan Pembangunan [Culture, Mentality and Development]. Gramedia, 1991. p. 29.

[5] Tjejep Rohendi. Metodologi Penelitian Seni. Semarang: Cipta Prima Nusantara, 2011. p. 212.

[6] Sulendraningrat, Sulaiman. Sejarah Cirebon [History of Cirebon]. Balai Pustaka, 1985.

[7] Cirebon, Kesultanan Kanoman. Babad Kanoman [Chronicle of Kanoman]. Cirebon: Tim Pustaka Wangsakerta, 2017.

[8] Cirebon, Kesultanan Kanoman. Sejarah Berdirinya Kesultanan Kanoman Cirebon [History of the Establishment of the Sultanate of Kanoman Cirebon]. 2011.

[9] Pamadhi, Hajar. Pendidikan Seni: hakikat kurikulum pendidikan seni, habitus seni, dan pengajaran seni anak [Art Education: the essence of art education curriculum, art habitus, and art teaching for children]. UNY Press, 2012. 